\title{
Changing Notions of "Ideal" Monkhood: A Case Study from a Satra of Majuli
}

\author{
Miss Pranalee Sharma ${ }^{+*}$ and Dr. Asha Singh ${ }^{\top}$
}

\section{Abstract}

All religions were initially founded with the aim of purifying men and women and helping them to lead ethical lives through prayers. However, unfortunately religion evolved to be a force reinforcing discrimination diverted from the original motive of religion. The Vaishnavite faith initiated by the 15th century Guru, Mahapurush Srimanta Shankardeva, in the region of Assam was also based on egalitarian and humanitarian values. The ideal monkhood in a Satra is to lead a life devoid of material pleasures and offer oneself to God by taking his name all the time. The various sects that have emerged after the demise of the Guru are the proofs that the main objective of an egalitarian society has collapsed. The social hierarchy is still maintained even if the Satras claim to have removed it. The unique culture of the Satra is its liturgical training, which includes dance, drama, music and poetry. The performing art forms were specifically for the monks to be performed only within the premises of the Satra, which are now staged and have become the sources of income for many monks. The monks are more known as performing artists than religious beings or leaders. The media is a socializing agent in itself, which has changed the concept of monkhood. Ideal monkhood is still a question, and this article is an academic effort to throw light on this question. It would try to bring forth the different ways as to how the ideologies of Neo-Vaishnavism has changed with time and how the monks have adjusted to the transformation. The findings are based on both primary and secondary data using ethnographic approach.

Key words: Majuli, Vaishnavism, Ethnography, Monastery, Modernity, Assam, India

\footnotetext{
${ }^{\dagger}$ PhD Scholar, Department of Human Development and Childhood Studies, Lady Irwin College, Email: pranaleesharma1989@gmail.com 


\section{Introduction}

In the state of Assam, Majuli, a river island and a newly declared district, is known to be the seat of Vaishnavite culture with its unique contribution to evolution of a subculture in the region. Majuli is a river island, on the river Brahmaputra, with extreme historical and cultural importance (Kotoky, Bezbaruah, Baruah, Sarma; 2003). Majuli has replaced Marajo island of Brazil to become the world's largest river island on September 2016 (Mitra, 2016). Majuli is now the first river island to be declared a district (35th district in Assam) in the country on 8 September 2016. Geomorphologically, Majuli forms a part of the flood plains of the river Brahmaputra (Kotoky et al., 2003). Majuli had an area of 1,256 sq. $\mathrm{km}$ in 1991 but due to extreme bank erosion, it has been reduced to 924.6sq.km (Census 2011).

Majuli is considered the hub of Neo-Vaishnavite culture since it has the highest number of cultural centres known as Satras (monasteries) than in any other places of Assam, some of which date back to the $15^{\text {th }}$ century. The culture and presence of the Neo-Vaishnavite faith is at risk due to the rapid erosive activity of the river.

Between $12^{\text {th }}$ and $15^{\text {th }}$ century A.D., India had faced much social discrimination based on the caste system ${ }^{1}$ approved of by the Vedic scriptures of Hinduism (Saikia, 2011; Dutta, 2014). Throughout the medieval period worship of goddesses and sacrifices was the leading religion of Assam from which even human beings were not exempt (Gait 2008). Such oppressive actions from the society led to the evolution of a renaissance in the form of Vaishnava Bhakti movement all over India. It was in this moment that Mahapurush Srimanta

\footnotetext{
${ }^{1}$ Caste system: There are four divisions of Hindu society - Brahmins, the priestly class enjoy the top most position followed by Kshatriyas, the military class. Vaishsyas come next the merchants' class and at the bottom is the Sudra, the artisans or the menial class (Ambedkar, 1916). Caste is considered immobile and hereditary. '...these sub-divisions...have lost the open door character of the class system and have become selfenclosed units called castes' (Ambedkar, 1916:24).
}

Shankardeva emerged in the state of Assam and initiated the present Neo-Vaishnavite faith in the region. "Shankardeva inculcated a doctrine of salvation by faith and prayer rather than sacrifices" (Gait, 2008:59).

Neo-Vaishnavism propagates the faith of "EkSaran-Nama-Dharma" which is the faith of taking the name of one God, that is, Lord Krishna. He wanted a society with no discriminations and sacrifices. He established numerous temporary congregational halls to perform various forms of devotional songs, dramas and dance as a way to preach his teachings (Saikia, 2011; Konwar, 2015). These temporary congregational halls later developed into Satras (monasteries). Satra is a place where the disciples live together as one community propagating the teachings of their leader Shankardeva. Satras are divided into two clutches based on their marital status named as Grihasthya Satras and Udasin Satras. Grihasthya means household and the bhakats (disciples) are called akewaliya disciples. They have families and live like any other community staying together at one place. The word udasin means a life of an ascetic, indifferent to worldly materials. Monks from Udasin Satras lead a celibate life and are called 'kewaliya' disciples. Udasin Satras are similar to the Buddhist and Jain monasteries (Goswamee and Das; 2013). This paper will only try to engage with the Satras that follow celibacy, that is, Udasin Satras.

There are certain ideals that are to be followed by monks in monasteries everywhere. Definition of ideal monkhood for one kind of monastery might be completely different from its counterparts. The Satra where celibate monks reside is named 'Udasin', an Assamese word which means 'ascetic' according to fourth edition of 'Hem-kosha' (1965). According to Ghurye (1952), the essence of asceticism lies in the renunciation of worldly ties. Essentially, there are four traits of asceticism: celibacy, austerity, concentration and ecstasy (Ghurye, 1952). The Satra seems to be much more liberal than its counterparts are. There lies flexibility in the hands of the Satra monks. The monks can 
leave the Satra anytime they wish to. The image of an ideal monk in a Satra is vague. According to Lanman (1917), asceticism in Hinduism states the abandoning of worldly possessions, fasting and continence as the main characteristics of an ascetic. As the word 'Udasin' suggests Satra monks are also expected to follow asceticism and its characteristics, which might be counted as the ideals of Satra monks.

The very fact that Satras as an institution have continued until today indicate their importance although their contemporary status in Assamese society is a poor shadow of their status in previous centuries. "Modernity is now everywhere, it is simultaneously everywhere, and it is interactively everywhere" (Appadurai and Breckenridge, 1995: 2). Forces of modernisation are difficult to escape. Modernity is a very complex subject and I would not be able to do full justice to it by defining it in this paper. Modernity in this paper is aligned with the modernity described by Eisenstadt (2010) as the growing urbanization, increasing commodification, development of communication and agencies of education. The technological progress has undoubtedly affected the lives of the monks. The continuous connection with the bigger and broader world through technology has led many monks to leave Satras. Though traditions ${ }^{2}$ and modernity has been balanced well by the Satras, such incidences are not uncommon. Narratives of monks describe that universalisation of education, ${ }^{3}$ a product of modernisation, has hampered the Satriya lifestyle yet they are encouraging children to study. Satras are accepting the importance of formal education

\footnotetext{
${ }^{2}$ For an understanding on the term tradition that augurs with the argument at hand one may see, Dipesh Chakrabarty, (2002), Habitations of Modernity: essays in the wake of subaltern studies. Here, Chakbrabarty is of the mind that tradition basically refers to the persistent effort on the part of an institution(s) to cull and leverage the best practices from a more distant past without necessarily romanticising it in entirety.

${ }^{3}$ Universalisation of education is the objective under Right to Education Act, 2010 that promotes free and compulsory education for every child between the six to 14 years (Sikdar \& Mukherjee, 2012).
}

over traditional education system. Monks of Satras do not live an isolated life rather involve with the community at various levels. Theatres, devotional songs, psalms, dance and many more art forms are medium to communicate with the society. Modernisation with the technological progress has helped Satras in communicating with the people in a smoother manner.

The population of monks in the monastic Satras is negligible as compared to the total population of the region. Majuli has a population of 167,304 persons (Census of India, 2011) with 31 Satras according to Majuli Cultural Landscape Management Authority. Out of these 31 Satras, only six Satras are Udasin Satras (Sarma, 2013). Yet the monks have a significant influence in the minds and lives of the people, as prominent religious leaders.

There is a gap in literature on the interrelation of monastic ideals and lives of the monks. The present article is a part of a larger study aimed to understand the lives of the children in Satras of Majuli. The study is an effort to bridge the gap and explore an area which is given relatively little attention in literature. The existing literature is largely limited to studies in aspects of the culture and art forms.

As stated above, this paper is a product of a larger study whose objective is to study the socialisation practices of children in Satras. It attempts to examine as to how has the contemporary forces transformed the monks and their lives.

The article begins with a brief explanation illustrating how the study was conducted. It is divided into three major parts which is followed by conclusion at the end. The section-'reestablishment of social hierarchy' argues how the Satras have maintained the caste stratification despite its ideals of equality. The second section-'dilution of ideals' discusses the present situation of the Satras. It goes on to explain how the Neo-Vaishnavite ideals and values have undergone changes over time. Following this, it discusses, about the effects of modernity on the performing arts forms of the Satras. 


\section{Methodology}

The method chosen for researching monks' experiences was an ecological approach with naturalistic observations as the major tool. The method rests on two grounds-one that individuals are firmly seated within the social and cultural context and the other that following and observing individual within their contexts gives a lot to learn about their lives. Thus, the study was conducted under natural setting inside the Satras. No effort was made to separate the individual from its context.

Realising the objectives of the study, it was necessary to have 'lived in' experiences and ethnography as methodological paradigms and reckoned to be the most appropriate to the context. To understand the lives of the monastics, an in-depth ethnographic study was conducted with an intensive engagement with the monasteries of Assam and its residents.

The study was conducted on four celibate Satras in Majuli. Out of 12 celibate Satras in Assam, six are located in Majuli. The data collection method took 6 months excluding the one-month pilot study period. Each Satra was observed and studied for one month. Three months were dedicated in staying with the villagers to understand the dynamics of the Satra and the society.

Observation in natural surroundings was the major tool of the study. Informal interviews of monks and devotees were conducted along with various techniques to engage with the children in the Satras like role-plays. Informed consent letters were provided to each Satra head and the monks with a detailed information sheet on the purpose of the study. Assent was taken from children before conducting interviews with them. Anonymity of the monks and the children has been maintained, and the research data is kept confidential.

\section{Re-establishment of Social Hierarchy}

"Shankardeva believed that renouncing the world would not spiritually uplift him if he is not in any service to humanity" (Saikia, 2011:55). However, Shankardeva's successor,
Madhavdeva remained a celibate and the monastic ideals grew vigorously in his days (Neog, 2008). After the demise of the leader, the objective of the faith diluted. Four sub-sects of Vaishnavism that emerged in the absence of the leader are-Brahman Samhati, Nika Samhati, Purush Samhati and Kaal Samhati.

One of his Brahmin disciples, Damodardeva, started a lineage of Satra with his rules in it. Dakhinpaat Satra is one of these Satras. Another Vaishnavite, Aniruddhadeva started a Satra for the downtrodden and tribes who were considered impure due to their food habits. His sub-sect is known as Kaal Samhati, where there are no restrictions on lifestyle. It was considered the most radical as per the teachings of Shankardeva; it flourished amongst the tribes and it had a large following among the lower castes (Sharma, 1996).

Similarly, Mathuradas Ata, a disciple and the followers of grandsons of Shankardeva started their own Satra sub-sects-Nika Samhati and Purush Samhati respectively, with subtle differences in their ideologies (Neog, 1998). The original idea of creating a society with no hierarchy vanished as soon as the four different sub-sects came into shape. Each of the four sub-sects claims to be the original follower of Shankardeva. Except for the Kaal Samhati Satras, the other three sub-sects of Vaishnavism underwent massive transformation and diversion from their chief goal. Guha (1983) states that in 1702 a royal verdict was announced which prohibited Sudra monk from initiating and sheltering Brahmins in their monasteries. The discarding of idol worship by any monastery was also made a penal offence. Henceforth, only conformist neo-Vaishnavite monasteries were given support by the royal families.

Monks who took vows to live a simple life deviated from the material world contradicted their own ideals. When one perceives the lifestyle of a monk, it is imagined as an ascetic who has abandoned this material world to find inner peace. The detachment is the identity and power of a monk. Renunciation has been considered as a value in Hinduism since early 
times. Renouncers are unconnected individuals who depart from the societal attachments. By renunciation, I try to focus only on the philosophy of the saint where he says to detach oneself from the worldly attractions and immerse into taking Lord's name. In Satras, monks try to bring forth the image of an ascetic who lives in poverty and follows unblemished and obedient life. The image in literature and the image shown to the people are contradictory to what the real life is. Material assets like mobile phones and televisions are common amongst the monks. An elder Monk shared that they are poor monks who live on alms and blessings of the people. What he meant was that sadly they are trapped in the vows that are forced on them at a very young age such as vows of staying an ascetic, to stay away from the temptations of the world, to always follow the norms of the faith, etc. These vows seemed as restrictions to the monks.

The children are keen observers and learners of the changing environment around. When they see elder monks arguing about land and property, the children find it difficult to understand the vow of living a life detached from the material world. The sole objective of a Satra, that is, to congregate and take Lord's name with like-minded people, is obliterated.

Majuli is an island densely populated by tribal communities mostly Mishing tribe followed by Deoris and Sonowal-Kacharis. Children in the Satra were seen mocking the one who looked different and had mongoloid features. Satras do not initiate anyone from tribal communities. Ahom community who ruled Assam as well as supported many Satras with great deal of endowments are excluded too. Young boys are socialised to inculcate the perception that anybody with mongoloid features is from the 'impure' group. Although the present chief Minister of Assam, Mr. Sarbananda Sonowal, who contested from Majuli, is a member of one of the tribal communities, the tribes of Majuli still bear hierarchically a lower status. Shankardeva in his version of Bhagavat Purana ${ }^{4}$

\footnotetext{
${ }^{4}$ Bhagavad Purana: A sacred text of the Vaishnava form of bhakti which is more tolerant and liberal since it says
}

substitutes the given list of impure people with the existing tribes of the northeast (Neog, 1998). Shankardeva too considered the tribes as impure people who needed cleaning through his Neo-Vaishnavism doctrine. Konwar (2015) mentioned an incident where a Brahmin head monk said to one of his monks that naming his two cows-Shankar and Madhav would upgrade the caste status of the two saints since they were both Sudras (lower castes).

At one time, the Satras did not allow the tribal communities to enter the premises. Nowadays, they are allowed to sit and sing devotional songs along with the other devotees but are still denied the right to become a monk. Satras believe that tribesmen are polluted since they brew their own beer, eat pork and cannot fit into the Satra routine. The early tradition of restricting their entry to the main prayer hall no longer exists. Currently, situations have changed immensely; now the discrimination is not very evident and visible. Konwar (2015) has written about a lower caste person who had to pay a fine of 3400 for entering the inner hall of the prayer hall. Obviously, caste discrimination has lessened but has not completely disappeared. Now with the increase in tourism, the monasteries fail to stop the pouring in of the tourists who can be of any castes/class or religion. There is a tussle between the values and the actions of the monks. Monks, at one point of time, were very particular about who should enter their premises. They did not allow people from other religion to enter whereas saint Shankardeva had 12 disciples from different ethnic backgrounds and different religions. The actions display that the white skinned people are not counted as people from different religions. An incident described by Allen (1927: 772) very well describes how the Satras perceive white-skinned foreigners.

When Lord Chelmsford visited Assam in 1920, the principal abbots (head monks), men of the greatest dignity and charm

that a devoted lower caste is more worthy of respect that a Brahmin who has no true devotion in heart (Gohain, 1987). 
of manner, asked to be allowed to present him with an address. The nationalist lawyers did all that they could to get the meeting boycotted, but the authority of the abbots and the desire to see the Viceroy made opposition futile. The villagers assembled in thousands round the great pandal in which the leading abbots, dressed in their robes of state, awaited the arrival of their distinguished guest.

Foreigners are regular tourists in the island. Tourists from all over the world are found exploring the Satras. When enquired about Muslims one said, "in the current situation, we cannot stop anybody since they are all tourists but Muslims are scared and prefer not to enter the premises of Satra. Foreigners are tolerated because it is not possible to identify their religious backgrounds". Satras like to guard themselves from the local Muslims probably not the foreigners. It serves us to pay attention to a commentator on Northeast issues who says, "Satras are living centres, the embodiment of Assamese culture and spirituality. They are inclusive and secular, as they welcome everyone. A Satra does not inflame Hindu religious sentiment" (Hazarika, 2016). His statement is misplaced in comparison to the narrative provided by the participant of my research.

Children pick up values quickly. A new entrant in the Satra had mongoloid feature but he did not belong to any tribe. He was around 11 years old and insisted on wearing red half-pants inside the Satra premises, which is generally not allowed. The other little monks teased him by saying "ronga pant doimari" where 'ronga pant' means red pants and 'doimari' is a common surname used by the Mishing tribe, which doubles up as an insult. This was witnessed by the elder monks without any qualms. In my observation, it was apparent that the younger children were simply following a script laid by the senior monks. It is apparent that a number of aspects relating to race, physical features and even clothing are brought under scrutiny in order to determine the entry of a child into the Satra.

Not all Satras are alike; there are some, which try to establish the caste hierarchy like Brahman Samhati Satras whereas there are other Satras like Mayamora Satra under Kaal Samhati, which tries to implement the saint's principles.

\section{The Dilution of Ideals}

The Satras do not have any nunneries. They only initiate male children. Women are excluded from the Satra institutions. Kakoti \& Mahanta (2012) argue that despite the great contribution towards Vaishnavism in Assam by Shakardeva's grand daughter-in-law, women are absent in the history of Neo-Vaishnavism. There are no women in priestly role after her. With time, Neo-Vaishnavism has become more conservative regarding the women folk. Dalton in his article on Mahapurushyas (1851) mentioned that women were only allowed to sit in the veranda of the prayer hall and to join in for some spiritual songs. Today, women can enter the prayer halls yet are excluded from the religious practices performed.

The boys who are initiated either are selected by the monks or are given by their parents as means of worship. Earlier reasons for giving away a male child was religious but now it is predominantly economic. Most of the young boys belong to lower socio-economic classes and majority belong to places affected by heavy and recurring floods.

Most of the children initiated into the Satras undergo a name change. There is a change in names when the original names are not synonymous to the name of Lord Vishnu and his incarnations.

Maheswar Neog (1998) states in his book 'Early History of Vaisnava faith and movement in Assam' that Shankardeva was highly influenced by Bhagavad Purana. His version of Bhagavad Purana is Bhakti-Ratnakara where he writes that purity of body and mind is necessary for devotion to God (Neog, 1998: 233). 
Shankardeva and his successor Madhavdeva's aim were to purify Hinduism from within (Neog, 1998: 360). If we take notice, the name of the Guru (Srimanta Shankardev), was named after Shankara, another name of Lord Shiva. "Modern names with no 'good' meaning needs to be changed", as one of the monks said: "names like Nabajyoti (new light), Rajiv (lotus flower), Bikash (growth) are not considered 'good' enough names and are changed to Mohan, Hari, Krishna, etc. which are different names of Lord Vishnu. Within the walls of Satra, something completely opposite of the saint's philosophy was being practiced.

Shankardeva believes in devotion and thus he preaches not to compromise on the devotion in Lord Krishna (incarnation of Lord Vishnu). He was against the blood sacrifices, a common practice among people following Shaktism ${ }^{5}$ (followers of Shakti or power that is, Goddess). Shaktism was the predominant form of Hinduism during the medieval period in Assam, and it is also believed that its origins lie in this region itself (Gait, 2008). Shankardeva was clearly against the worshipping of Goddesses, which he strictly applied to Neo-Vaishnavism. The later monks misinterpreted it to preach that other faiths are inferior to Vaishnavism. The ideals here are here taking a different turn where the 'other' is seen as inferior. One can notice the difficulty amongst the monks to accept people from other faiths.

Shankardeva also preached that the mere utterance of One and Only God, Lord Krishna is enough as a way of worship. He was against the worship of Idols (Dalton, 1851). Shankardeva writes in his Bhakti-Ratnakara, "if the bhakti or devotion is vitiated then do not worship other gods or goddesses, do not enter their temples and do not cast glances on their idols" (Neog, 1998: 362). His followers only keep the religious book "Bhagavad" on the altar. The present day Satras have installed idols of Lord Vishnu and Lord Krishna inside their prayer halls. This is

\footnotetext{
${ }^{5}$ Shaktism: It is the path of Hinduism where the divine feminine is worshipped in the form of powerful and terrifying Goddesses like Kali, Durga and Devi (Peabody, 2009).
}

contrary to the teachings of Srimanta Shankardeva.

At present, the Satras which were following the Brahman legacy worship the idols and only allow Brahmans to perform various Vedic rituals related to worshipping God. Bloody sacrifices do not take place in any of the Satras. It is one of the very few ideals that have persisted even after so many years. Among the celibate Satras, Auniati Satra and Dakhinpaat Satra have idols of both Lord Krishna and Vishnu, which are taken special care by the Brahman monks. These are also those Satras where the head monk has to be from a Brahman family. Here I would like to add that the caste system in Assam is less rigid than the rest of the country. The introduction of functional grouping into the society by the Ahom kings made the caste system flexible (Chauhan, 1980). Although the social hierarchy that prevailed during Shankardeva was oppressive towards the lower castes, there were Sudra and tribal communities who ruled different areas of the state. Assam was ruled by the Ahoms, an offshoot of the Tai or Shan race (Gait, 2008), for more than 600 years. Hinduisation was stirring in gradually. By the mid-17th century, the Ahoms became Hinduised (Eraly 2000). Shankardeva as well as his successor Madhavdeva were from Kayastha community, a lower caste. With the initiation of the Neo-Vaishnavite faith, the caste hierarchy diluted to some extent. "Shankardeva raised himself and his Sudra disciples to a higher religious status with powers equal to Brahmins. Shankardeva became the Guru of Brahmins and also gave religious precepts to the Brahmins" (Neog, 1998: 360), although few of the Brahmin disciples preferred to stick to their Vedic religious practices.

The ideals of an egalitarian society with no discrimination between any castes no longer existed when the Brahmin sect Satras decided to maintain the caste hierarchy.

\section{Performing Art: Devotion or Profession?}

Shankardeva apart from bringing in equality also invented new forms of performing arts like Theatre called Bhaona (Neo-Vaishnavite 
theatre form), Ankiya Naat, dance form called Sattriya; music in the form of Borgeet, NaamKirtana, Bhotima, Protima, etc. Songs, dance, and music bear an inseparable connection with the Satras. His tools in preaching were predominantly the performing arts he created. The art forms functioned as the catalysts in promoting the faith. The performing arts have now been an inevitable part of the Satras and the Neo-Vaishnavite faith in Assam. The art forms were performed for the God and only inside the Prayer hall. We cannot rule out the effort put in by the monks to preserve the art forms introduced by the Guru of NeoVaishnavite faith.

With the advent of modernisation, the performing art forms have moved beyond the Vaishnavite institutions and have diluted in some nuanced forms. Bhaonas started being staged, competitions are organised, and technologies like sound systems, microphone, and light arrangements are introduced. Subsequently, the performing art forms moved beyond the sacred walls of the Satras. Monks have travelled to different parts of the world to perform. Sangeet Natak Academy, The National Academy of Music, Dance and Drama recognised Sattriya dance as a classical tradition of India in 2000 (Tamuli, 2014).

Bhaonas used to be a nightlong performance during auspicious occasions inside the prayer halls. Now it is reduced to few hours. Bhaonas are now organised on any occasion be it a wedding, a religious function or even a death anniversary.

Sattriya dance form has also undergone changes. There are no gender restrictions as before. Women are equally performing Sattriya dance on various platforms. The first movement of the dance form from the sacred space of Satra to a secular space was in the $18^{\text {th }}$ century in the royal court of Ahom King, Rajeshwar Singha (Tamuli, 2014).

Monks with greater knowledge of the dance form take dance classes, few others teach music, and some teach the musical instruments while some prefer to become Vaishnavite priests. Vaishnavite priests perform religious functions for the people, take care of the village prayer halls and in return are paid a small amount from the community. The art forms were the only skills the monks could make use of for their livelihood. The monks are now identified more as performing artists. Children are initiated into the Satras with the hope that they would in future learn the art and could feed themselves and their families, if they make any. Once a child of about 13 years of age said, "I am here for a few days. My parents sent me here to learn the art forms so that I can go back and earn".

However, the monks have taken the vows of being away from the material world but the liturgical training within the Satra fails to bestow them enough space to exercise the vows. This signal a clear disconnect between the path chosen by the monks and their lifestyles.

The children save money from their performances usually to buy latest smart phones. These smart phones generally do not have sim cards but only memory cards in it. Phones are hardly used for communication rather used for storing materials like pictures, music, videos, etc. The Satras are not being able to communicate the purpose of NeoVaishnavism to the little monks. Dakhinpaat Satra, a Brahman Samhati Satra, has a residential Veda ${ }^{6}$ school where they teach the young boys everything that is taught to monks. The only difference is that these boys do not have to take any vow of becoming an ascetic. The intent was to propagate the values and preaches of the saint. Since this Satra has a very low population of young monks, the head monk decided not to limit the monastic education of Neo-Vaishnavism only to monks and introduced a system where the values of Neo-Vaishnavism always remain alive. After the education if anybody wishes to stay back in the Satra, they can. Satra is cushioning the little monks to find ways on how to stay within the material world and yet be an active member of

\footnotetext{
${ }^{6}$ Veda: Earliest religious scriptures, which are considered to have temporal manifestations of eternal and transcendent knowledge (Olivelle, 1992:3).
} 
it. The contemporary forces are acting at a great force on them even inside a little island Majuli with very limited communication.

\section{Conclusion}

The complex intertwining of the ideals, beliefs have corrupted the basic philosophy of bhakti; religion of love (Gohain, 1987). The caste hierarchies, the attitude towards the tribes, the absorption of worldly possession rather than abandoning it, etc. are some of the reasons for the labyrinth. Sarma (2013) in his article on celibate Satras of Assam titled 'Monastic Sattras of Assam' states that the celibate Satras have managed to retain their old values and philosophy especially in case of dress, dialect, sitting arrangement, ways of life, house types, cultural activities etcetera. However, the celibate Satras has lost most of its old values and philosophy. From the discussion in this paper, it is evident that Sarma's statement is debatable. The only thing Satra could keep alive is the performing art forms. Modernity has engulfed the celibate Satras too unlike what Sarma has said. Materials assets have become the priority in the lives of monks. Is Satra being diluted with the rapid changes within or it is trying to survive encompassing all the modernity around? That is a question, which does not have one answer to it.

There is much more to explore on the transformation they have undergone since its inception. Whatever transformation I have witnessed is enough for me to say that no matter how strong traditions bind change is an inevitable aspect of society. No one can stop the dynamic nature of social change. Society has been transforming since ages and it will keep changing in various ways.

\section{Reference}

Allen, B. C. (1927). Assam. Journal of the Royal Society of Arts, 764-786.

Ambedkar, B.R. (1916). Castes in India: Their Mechanism, Genesis and Development, presented at Anthropology Seminar of Dr. A.A. Goidenweiser, Columbia University, New York, 9 May (pp. 1-32). Jullundur: Patrika Publications
Appadurai, A. and C.A. Breckenridge (1995). Public Modernity in India. In C.A. Breckenridge (Ed.), Consuming Modernity: Public Culture in a South Asian World (pp. 1-20). Minneapolis: University of Minnesota Press.

Barua, H. C. (1965). The Assamese-English Dictionary Hem-Kosha. Hem Chandra Library.

Census of India (2011). District Census Handbook Jorhat: Village and Townwise Primary Census Abstract (PCA). Retrieved September 29, 2016, from http://www.censusindia.gov.in/2011cen sus/dchb/1813_PART_B_DCHB_JORHAT .pdf

Chakrabarty, D. (2002). Habitations of Modernity-Essays in the Wake of Subaltern Studies. Chicago: The University of Chicago,

Chauhan, S. K. (1980). Caste, Status \& Power: Social Stratification in Assam. New Delhi: Classical Publishing Company.

Dalton, E. T. (1851). Mahapurushyas. Journal of the Asiatic Society of Bengal.

Dutta, M. (2014). Bhakti Movement: A Socioreligious Struggle of the Marginalised Society. Indian Journal of Applied Research, pp.685-687.

Eisenstadt, S.N. (2010). Modernity and Modernization. Sociopedia.isa, pp.1-15. doi: $10.1177 / 205684601053$

Eraly, A. (2000). Emperors of the Peacock Throne. Gurgaon: Penguin Books India.

Gait, E. (2008). A History of Assam. Guwahati: EBH Publishers.

Ghurye, G. S. (1952). Ascetic Origins. Sociological Bulletin, 162-184.

Gohain, H. (1987). The Labyrinth of Bhakti: On Some Questions of Medieval Indian History. Economic and Political Weekly, 1970-1972.

Goswamee, G., \& Das, S. (2013). A Study of Value Pattern of Inmates of Monastic 
Satras of Assam, India. The Clarion, 147151.

Guha, A. (1983). The Ahom Political System: An Enquiry into the State Formation Process in Medieval Assam (1228-1714). Social Scientist, 3-34.

Hazarika, S. (2016). Hindutva's Quiet Entry in Assam. Hindustan Times, Retrieved June 15, 2016, from http://m.hindustantimes.com/static/hin dutvas-quiet-entry-in-assam/

Kakoti, P., \& Mahanta, P. J. (2012). Understanding Women in the Religious Institutions: A Study With Reference To the Sattras of Assam. Journal of Humanities and Social Science, 19-22.

Konwar, D. N. (2015). Sankare Pate Bhakate Bhange. Guwahati: Assam Book Trust.

Kotoky, P., Bezbaruah, D., Baruah, J., \& Sarma, J. N. (2003). Erosion activity on Majuli the largest river island of the world. Current Science, 929-932.

Lanman, C. R. (1917). Hindu Ascetics and Their Powers. Transactions and Proceedings of the American Philological Association, 133-151.

Majuli Cultural Landscape Region. (n.d.). Retrieved September 25, 2016, from http://majulilandscape.gov.in/sattra.ph $p$

Mitra, N. (2016, September 2). Majuli named world's largest river island. Times of India. Retrieved September 8, 2016, from http://m.timesofindia.com/city/guwaha ti/Majuli-named-worlds-largest-riverisland/articleshhow/53972804.cms

Neog, M. (2008). Early History of the Vaishnava Faith and Movement in Assam. Guwahati: LBS Publications.

Olivelle, P. (1981). Contributions to the Semantic History of Samnnyāsa. Journal of Americal Oriental Society, 265-274.

Peabody, N. (2009). Disciplining the Body, Disciplining the Body-Politic: Physical Culture and Social Violenceamong North Indian Wrestlers. Comparative Studies in Society and History, 372-400.

Saikia, N. (2011). Bisay: Shankardeva. Dibrugarh: Kaustubh Prakashan.

Sarma, K. (2013). Monastic Sattras of Assam. The Clarion, 152-166.

Sharma, C. K. (1996). Socio-Economic Structure and Peasant Revolt: The Case of Moamoria Upsurge in the Eighteenth Century Assam. Indian Anthropologist, 33-52.

Sikdar, S., \& Mukherjee, A. N. (2012). Enrolment and Dropout Rate in School Education. Economic and Political Weekly, 27-31.

Tamuli, K. (2014). Desi and Margi Interpretation in Sattriya Nrittya. International Journal of Advanced Research, 1-11. 